\title{
Czerwony horyzont marzeń
}

Zastanawiać się nad tym, czy poza kapitalizmem istnieje życie ludzkie i jak wyglądałby alternatywny model społeczeństwa, to ryzykować, że wyląduje się na stoku utopijnych spekulacji, abstrahujących od niepewnego przebiegu walk klasowych i niewiadomych układów sił politycznych ${ }^{1}$.

Powyższy cytat z książki Daniela Bensaïda powinien być przestrogą dla każdego zaangażowanego badacza, który chciałby określić potencjalne źródła postkapitalistycznego porządku społecznego. Jak pokazuje przykład książki The Communist Horizon Jodi Dean, cienka jest granica między praktykowaniem utopistyki a kreowaniem utopijnych perspektyw. Łatwo można tą granicę przekroczyć, gubiąc z widoku tytułowy horyzont komunistyczny.

Jodi Dean w swojej książce próbuje nakreślić dynamikę i przyszłość ruchu protestu, który rozwinął się jako odpowiedź na kryzys w ramach kapitalistycznego systemu-świata. Pozostaje przy tym krytyczna wobec najpopularniejszego elementu tego ruchu, jakim było Occupy Wall Street $^{2}$. Dla Dean głównym ograniczeniem skuteczności okupujących jest

1 D. Bensaïd, Wywtaszczeni: Marks, wtasność i komunizm, tłum. Z.M. Kowalewski, Warszawa 2010, s. 109.

2 Niestety w książce nie zostało jasno określone, co autorka rozumie przez Occupy Wall Street - czy chodzi o ruch społeczny w Stanach Zjednoczonych, oku- 
brak ustrukturyzowania działań w formie partii politycznej. Będąc wierną uczennicą Slavoja Žižka, uznaje, że „polityka bez partii to nie polityka”3. Jej zdaniem tylko zorganizowany w ten sposób podmiot ma potencjał rewolucyjny, tylko w taki sposób ten podmiot może podążać ku horyzontowi komunistycznemu.

To kluczowe dla książki stwierdzenie poprzedza wieloaspektowa redefinicja idei komunizmu, oczyszczona z przesądów, jakimi zwykło się obsadzać przymiotnik „komunistyczny”.

Celem książki jest rehabilitacja pojęcia „komunizmu”, które zdaniem Dean zastępowane jest współcześnie postkapitalistycznymi eufemizmami. Wynika to przede wszystkim ze zwycięstwa neokonserwatywnej narracji na temat historii Związku Radzieckiego oraz, co gorsza, jej akceptacji przez środowiska lewicowe. „Utrata z widzenia horyzontu komunistycznego", twierdzi autorka, przyczynia się do politycznej słabości lewicy ${ }^{4}$. Główny problem recenzowanej książki polega jednak na tym, że alternatywna narracja Dean nie jest jakościowo inna od jednostronnej opowieści prawicy o bloku państw socjalistycznych.

Autorka The Communist Horizon sądzi, iż antagonizm na poziomie polityki międzynarodowej między USA a ZSRR miał charakter pozorny. Pomimo iż oba supermocarstwa były w istocie elementami jednego systemu globalnego, to zostały przeciwstawione sobie symbolicznie. Kreowanie ciąłego zagrożenia wojną atomową pomogło w kształtowaniu zimnowojennych tożsamości oraz podporządkowało ludzi państwowym aparatom bezpieczeństwa po obu stronach Żelaznej Kurtyny ${ }^{5}$.

Jednakże Dean twierdzi, iż na poziomie polityki społecznej istniały znaczące różnice między dwoma antagonistami, zaś ZSRR stanowił dla USA czynnik motywujący do egalitaryzacji amerykańskiego społeczeństwa. Jej zdaniem wprowadzenie zabezpieczeń socjalnych w Stanach w ciągu dwudziestego wieku wynikało z tego, że kraj ten pod względem populacji wypadał zdecydowanie nieegalitarnie w porównaniu do „Kraju Rad”. Amerykańska filozofka cytuje dysydenta, który opisuje ZSRR jako państwo z wszelkimi bytowymi i socjalnymi zabez-

pacje w całym zachodnim świecie, czy o grupę protestujących w Parku Zuccotti. Wnioskuję, iż chodzi o to ostatnie.

3 J. Dean, The Communist Horizon, New York 2012, s. 19.

4 Tamże, s. 3-6.

5 Tamże, s. 24. 
pieczeniami ${ }^{6}$. Cytat ten służy jej do zbudowania opisowej alternatywy na temat Związku Sowieckiego, którą przeciwstawiła mainstreamowej narracji o dyktaturze oraz braku wolności obywatelskich. Takowa perspektywa jest jednak ograniczona w dwóch istotnych aspektach.

Pierwszy z nich sprowadza się do konstruowania opowieści o realnym kapitalizmie w opozycji do dwudziestowiecznych państw socjalistycznych ${ }^{7}$, co de facto uwłacza wiedzy i inteligencji czytelników z Europy Środkowo-Wschodniej. Autorka nie problematyzuje kwestii tego, iż państwa typu leninowskiego były przede wszystkim środkami modernizacji peryferyjnej, a nie realizacją utopii komunistycznej rodem z Manifestu. Projekty modernizacyjne z jednej strony przyniosły np. populacjom środkowoeuropejskim awans społeczny, dzięki procesom urbanizacji, industrializacji, budowy silnego sektora publicznego, który był zdolny do koordynacji procesów społeczno-gospodarczych ${ }^{8}$. Z drugiej strony należy jednak pamiętać, że nadal był to pewien wariant kapitalizmu' ${ }^{9}$ w ramach którego posiadaczem środków produkcji była centralna biurokracja polityczna ${ }^{10}$. System biurokratyczny niósł ze sobą wyzysk, który co do istoty nie był odmienny od zachodnio-kapitalistycznego $^{11}$ - robotnikowi nadal odbierano produkt dodatkowy przemocą, wykorzystując go w celach, które są mu obce i wrogie ${ }^{12}$.

Drugim ograniczającym aspektem jest jednostronna narracja na temat przemian w USA, wedle której to kapitał czyni ustępstwa wobec klasy robotniczej ze względu na zagrożenie Związku Radzieckiego. Podstawową przyczyną wprowadzenia opieki społecznej i praw obywatelskich było bowiem wedle Dean pragnienie nieodstawania od prospołecznych rozwiązań ZSRR. Tego typu opis wyklucza oraz umniejsza rolę walk robotników, chcących kształtować warunki własnej egzysten$\mathrm{cji}^{13}$. Społeczne reformy w dwudziestowiecznych Stanach Zjednoczonych były bezpośrednio efektem wewnętrznych walk robotniczych i lęku przed obaleniem władzy kapitału, zaś strach administracji ame-

6 Tamże, s. 30.

7 Tamże, s. 34.

8 J. Majmurek, PRL jako projekt modernizacji peryferyjnej, w: PRL bez uprzedzeń, red. J. Majmurek, P. Szumlewicz, Warszawa 2010, s. 75.

9 J. Sowa, Ciesz się, późny wnuku!: Kolonializm, globalizacja i demokracja radykalna, Kraków 2008, s. 368.

10 J. Kuroń, K. Modzelewski, List otwarty do partii, w: J. Kuroń, Dojrzewanie. Pisma polityczne 1964-1968, red. S. Liszka, M. Sutowski, Warszawa 2009, s. 13.

11 A. Pannekoek, Workers' Councils, Oakland 2003, s. 17.

12 J. Kuroń, K. Modzelewski, List otwarty do partii, s. 73.

13 M.A. Lebowitz, Beyond Capital: Marx's Political Economy of the Working Class, Basingstoke 2003, s. VIII. 
Teza głosząca, że wzorowanie się

na nowoczesnych

projektach

modernizacyjnych może pomóc we współczesnej

realizacji idei

komunistycznych

jest trudna

do zaakceptowania.

Jej przyjęcie nijak

nie przybliża lewicy

do aktualizacji pojęcia

komunizmu, jak również

do narracyjnego

zwycięstwa nad

neokonserwatywnym

opisem historii dwudziestego wieku. rykańskiej przed sowiecką alternatywą pełnił zaledwie rolę uzupełniającą i wspomagającą wobec oporu robotniczego. Fordyzm, który współcześnie kojarzy się z zabezpieczeniami socjalnymi i uzwiązkowieniem, w swojej pierwszej fazie był autorytarnym systemem produkcji, w ramach którego robotnicy nie mogli kolektywnie negocjować warunków pracy. Na porządku dziennym były w nim zastraszanie i bezpośrednia przemoc wobec pracujących ${ }^{14}$. Do założenia związku zawodowego w fabryce Forda dochodzi dopiero w 1941 roku $^{15}$ po długoletnim cyklu walk między kapitałem a pracą ${ }^{16}$.

Teza głosząca, że wzorowanie się na nowoczesnych projektach modernizacyjnych może pomóc we współczesnej realizacji idei komunistycznych jest trudna do zaakceptowania. Jej przyjęcie nijak nie przybliża lewicy do aktualizacji pojęcia komunizmu, jak również do narracyjnego zwycięstwa nad neokonserwatywnym opisem historii dwudziestego wieku.

\section{II}

Jodi Dean w The Communist Horizon nie ogranicza się do omówienia dyskursywnych walk o historię. Jest to dla niej zaledwie środek do celu, jakim jest organizacyjne uformowanie współczesnego podmiotu antykapitalistycznego.

Autorka twierdzi, iż odrzucenie idei komunizmu przez lewicę przyczynia się do słabości ruchów rewolucyjnych, ponieważ powstałej w ten sposób ideologicznej pustki nie wypełniają w żaden sposób idee demokracji i partycypacji społecznej ${ }^{17}$. To główna słabość ruchów Nowej Lewicy oraz Occupy Wall Street. Pojęcia takie jak horyzontalizm, demokracja bezpośrednia oraz autonomia nie zrywają, zdaniem Dean, z panującą ideologia, ponieważ sama nawołuje ona do partycypacji w strukturach społeczeństwa obywatelskiego oraz gloryfikowania wolności indywidualnej. Główny zarzut autorki recenzowanej książki głosi, że owa horyzontalna forma działania jest trwałym elementem wspótczesnego środowiska neoliberalnego ${ }^{18}$. Przykładowo taka firma jak Google odrzuca

14 F. Gambino, Krytyka fordyzmu w wydaniu szkoty regulacjonistycznej, w: Pisma rewolucyjne w polityce postpolitycznej, red. W. Bonefeld, Poznań 2012, s. 105.

15 Tamże, s. 108.

16 D. Sherry, Occupy!: A Short History of Workers' Occupations, London 2010, s. $72-76$.

17 J. Dean, The Communist Horizon, s. 56-57.

18 Więcej na ten temat: J. Dean, Democracy and Other Neoliberal Fantasies: Communicative Capitalism and Left Politics, Durham 2009. 
hierarchiczną i biurokratyczną organizację przedsiębiorstwa na rzecz partycypacyjnego procesu zarządzania, spłaszczania struktur oraz uczynienia pracy bardziej elastyczną, kreatywną i interesującą̨ ${ }^{19}$. Jednakże Google nadal pozostaje przestrzenią wyzysku, zaś spłaszczenie struktur idzie w parze z intensyfikacją kontroli - już nie jedynie nad pracownikami najemnymi, lecz wszystkimi, którzy funkcjonują w sieciach informatycznych.

Dla amerykańskiej filozofki wniosek jest jednoznaczny: OWS swoim sposobem działania wpisuje się w krytykę biurokracji i regulacji, czyli przedmiotów neoliberalnych ataków na państwo społecznego dobrobytu $^{20}$. Horyzontalizm jest zatem trwałym elementem tzw. kapitalizmu komunikacyjnego, zaś ideały dostępu, włączenia i partycypacji realizują się, przybierają materialną formę w ramach globalnych sieci telekomunikacji ${ }^{21}$. Dean przestrzega nas równocześnie przed złudnością myślenia, iż mamy do czynienia z jakąś formą ,komunizmu kapitału": technologie informatyczne stały się wyłącznie nowym środkiem podporządkowania ludzi zasadom konkurencyjności neoliberalnego kapitalizmu oraz narzucania pracy ${ }^{22}$.

Z powyższych względów autorka The Communist Horizon nie znajduje w obrębie współczesnego kapitalizmu materialnych przesłanek dla walki klas, ani rozwinięcia idei komunistycznych. Odrzuca ${ }^{23}$ dlatego m.in. postoperaistyczną koncepcję wielości Michaela Hardta i Antonio Negriego, widząc w niej naiwną opowieść o dobrodziejstwach technologii w stylu Hakima Bey'a ${ }^{24}$. Ponownie w teorii Jodi Dean ujawnia się problem związany z nieumiejętnością aktualizacji idei marksistowskich, tym razem tych, które dotyczą ,fizjologii walk klasowych”25. Sądzę, że podejście post-operaistyczne przynosi ciekawsze efekty poznawcze, ponieważ samoorganizacja klasy robotniczej zawsze była wzorowana na podziale pracy w ramach ówczesnego sposobu produkcjii ${ }^{26}$. Należy zatem wnioskować, że tak jak hierarchiczny model fabryki był wzorem dla partii robotniczej, tak również horyzontalna sieć przepływów informatycznych może być podstawą dla

19 Tejże, The Communist Horizon, s. 125.

20 Otwarcie ta kwestia pojawia się w wywiadzie nt. książki: http://www. counterpunch.org/2013/07/11/admitting-the-communist-desire/

21 J. Dean, The Communist Horizon, s. 123.

22 Tamże, s. 124.

23 Tamże, s. 19 i 123.

24 H. Bey, Tymczasowa Strefa Autonomiczna, tłum. I. Bojadżijewa, J. Karłowski, Kraków 2010.

25 A. Negri, D. Muhlmann, Luksemburgizm byt nasza filozofia: z Antonio Negrim rozmawia David Mublmann, „Praktyka Teoretyczna” 2012, nr 6, s. 83.

26 K. Król, Autonomia robotnicza, Poznań 2007, s. 67. 
organizacji walki w dwudziestym pierwszym wieku ${ }^{27}$. Przez odrzucenie tego schematu myślenia Dean nie dostrzegła społecznego pochodzenia współczesnego elastycznego kapitalizmu, który ma swoje źródła w walkach klasowych w obrębie welfare states $^{28}$. Ceną za zabezpieczenia socjalne i poprawę warunków pracy w dwudziestym wieku było zasklepienie w ramach organizacji parlamentarnych (partie socjaldemokratyczne, komunistyczne) oraz organizacji związkowych, które broniły partykularnych interesów danego sektora pracy. Nowe ruchy społeczne zakwestionowały porozumienie między kapitałem a zinstytucjonalizowanym ruchem robotniczym. Celem nie była emancypacja - włączenie grup wykluczonych w kapitalistyczne struktury, lecz walka przeciwko ustalonemu reżimowi pracy i czasu wolnego, które były legitymizowane przez dwie powyższe formy reprezentacji ${ }^{29}$. Odpowiedzią kapitału był elastyczny model pracy oraz powołanie do życia państwa neoliberalnego, które nawet jeśli nie dokonywało jego całkowitej prywatyzacji, to wprowadziło logikę rynkową do sektora publicznego ${ }^{30}$.

Wraz z nową, neoliberalną fazą walk - główną figurą stał się robotnik uspołeczniony, któremu kapitalistyczne reżimy pracy i wyzysku narzucają elastyczny, prekarny oraz mobilny sposób życia ${ }^{31}$. Działalność intelektualna stała się bezpośrednio produktywna, opierając się na przywłaszczeniu społecznej komunikacji32. Jakościowo zmieniło to walkę klasową 33 , która przechodzi fazę eksperymentowania z nowymi formami organizacyjnymi ${ }^{34}$. Nie mamy już do czynienia jedynie z proletariatem wielkoprzemysłowym, lecz z o wiele bardziej skomplikowaną strukturą - gdzie oprócz robotników znajdziemy studentów z perspektywą całożyciowej spłaty długu, młodzież wywodzącą się z miejskiej biedoty ${ }^{35}$. Oprócz przedstawicieli tzw. working poor - bezrobotnych, jak również

27 M. Hardt, Praca afektywna, „Kultura Współczesna” 2012, nr 3.

28 H. Cleaver, Kategorie marksistowskie, kryzys kapitatu i wspótczesne konstytuowanie się podmiotowości spotecznej, w: Pisma rewolucyjne w polityce postpolitycznej, s. 51.

29 J. Bednarek, Polityka poza forma: Ontologiczne uwarunkowania poststrukturalistycznej filozofi polityki, Poznań 2012, s. 351-352.

30 D. Harvey, Neoliberalizm: Historia katastrofy, tłum. J.P. Listwan, Warszawa 2008.

31 M. Hardt, A. Negri, Rzecz-pospolita: Poza wtasność prywatna i dobro publiczne, tłum. Praktyka Teoretyczna, Kraków 2012, s. 144.

32 H. Cleaver, Kategorie marksistowskie, s. 59; P. Mason, Skad ten bunt?: Nowe swiatowe rewolucje, tłum. M. Sutowski, wstęp E. Bendyk Warszawa 2013, s. 198-203.

33 Tamże, s. 194.

34 M. Castells, Sieci oburzenia i nadziei: Ruchy spoteczne w erze Internetu, tłum. O. Siara, Warszawa 2013, s. 175.

35 P. Mason, Skąd ten bunt?, s. 94. 
względnie większą liczbę kobiet-partycypantek, niż mężczyzn ${ }^{36}$. Odrzucenie tradycyjnych form uprawiania polityki (partie i związki zawodowe) oraz niechęć wobec podporządkowania się spójnej ideologii socjalistycznej ${ }^{37}$ przez tę zróżnicowaną grupę powinno skłaniać środowiska lewicowe do przeformułowania strategii rewolucyjnej.

III

Niechęć do poszukiwania materialnych przesłanek dla walki klas prowadzi wywód Dean na manowce. Amerykańska filozofka proponuje jedynie stare schematy dla nowej sytuacji społeczno-ekonomicznej - dla niej Occupy Wall Street uskuteczniłoby swoje działania, gdyby zorganizowało się $\mathrm{w}$ partię polityczną ${ }^{38}$. Zgodnie z tą logiką zainaugurowanym w 2011 roku ruchom protestu brakowało wspólnej linii działania i platformy zbliżonych poglądów, które zjednoczyłyby wielość protestujących. Ruch Occupy, przez odrzucenie możliwości zinstytucjonalizowania się w formie zhierarchizowanej partii, żąda, zdaniem Dean, „rewolucji bez rewolucji” ${ }^{39}$.

Autorka poddaje krytyce także metodę konsensusu, która utrudnia „okupantom” mocne przeciwstawienie się kapitalizmowi i przejęcie kolektywnej kontroli nad wspólnymi zasobami. Inkluzyjność ruchu wiąże się z jego postideologicznością, oznaczając w istocie odrzucenie wprowadzających podziały ideologii ${ }^{40}$. Dean przestrzega, by nie zachwycać się technikami działania OWS, ponieważ indywidualistyczna autonomia uniemożliwiła mu podjęcie wspólnego działania, zaś horyzontalizm przyniósł rozluźnienie organizacji (nikt za nic nie odpowiada) ${ }^{41}$. Okupacja pojmowana jest jako łatwe do zaaplikowania zasady, które mogą być i są zastosowane do elastycznego kapitalizmu. W takim ujęciu OWS nie jest miejscem produkcji politycznych podmiotowości, lecz platformą, która może zostać użyta przez kogokolwiek do czegokolwiek ${ }^{42}$.

Dean porusza również kwestię reprezentacji, twierdząc, że OWS jest ruchem reprezentującym 99 procent społeczeństwa amerykańskiego ${ }^{43}$. Jej

36 M. Castells, Sieci oburzenia i nadziei, Warszawa 2013, s. 165.

37 M. Hardt, A. Negri, Declaration, New York 2012, s. 8.

38 J. Dean, The Communist Horizon, s. 56-57.

39 W.I. Lenin, Rewolucja u bram: Pisma Lenina z roku 1917, wybór S. Žižek, tłum. J. Kutyła, Kraków 2007, s. 596.

40 J. Dean, The Communist Horizon, s. 208.

41 Tamże, s. 210.

42 Tamże, s. 222.

43 Tamże, s. 219-229.

Niechęć

do poszukiwania materialnych przesłanek dla walki klas prowadzi wywód Dean

na manowce 
zdaniem również w obrębie samego obozowiska Occupy mamy do czynienia z grupami reprezentacyjnymi - z liderami o wyższej pozycji społecznej, względnie bardziej aktywnymi i angażującymi się działaczami itp. Dodatkowo, Dean zarzuca burżuazyjne odchylenie wszystkim tym, którzy twierdzą, iż istnieje coś takiego jak podmiot, który może w pełni racjonalnie samostanowić o sobie i o swojej wspólnocie. Jednostkowe podmioty nie są do końca świadome pragnień i motywów, które nimi kierują. Ktoś musi owym podmiotom wskazać niedostrzegalne przez nich pragnienie - w tym wypadku pragnienie komunizmu winno być im zaszczepione przez reprezentacyjną partię.

Jak przystało na lacanistkę, Dean pojmuje relację partii i mas niczym stosunek psychoanalityka i badanego prowadzonego przez meandry jego własnej psychiki ${ }^{44}$. Tak jak nie sposób dokonać autoanalizy psychiki, tak proletariat nie jest w stanie spontanicznie, oddolnie dotrzeć do swojej prawdy. Musi dotrzeć do niej z zewnątrz, dzięki zawodowym rewolucjonistom ${ }^{45}$.

Dominacja liderów o wyższej pozycji społecznej w ramach obozowiska Occupy Wall Street wiąże się w istocie z hierarchizacją i ograniczeniem roli słabszych, co w żadnym stopniu nie jest nową formą przedstawicielstwa ${ }^{46}$, ponieważ zachowuje podstawową cechę systemu reprezentacji parlamentarnej. Jest nią wspieranie osób dominujących w ramach struktur klasowych, które posiadają lepszy dostęp do sfery publicznej z racji zakumulowanego kapitału materialnego, społecznego, kulturowego ${ }^{47}$.

Abstrahując na moment od analizy Dean, warto wskazać również na te ograniczenia w ramach ruchu Occupy, które wynikają nie tylko z różnic kulturowych, ale przede wszystkim z tego, co nazywane jest sylogistycznym zapośredniczeniem ${ }^{48}$. W praktyce sprowadza się to do podziałów i konfliktów w obrębie klasy robotniczej, które są generowane przez kapitał. Zjawisko to oznacza, że jeden element klasy robotniczej pośredniczy w kapitalistycznym wyzysku drugiego: mężczyźni wobec kobiet, imigranci wobec obywateli kraju ${ }^{49}$, itd. Jaką mamy mieć pewność, że w czasie trwania realnego kapitalizmu na demokratycznym plenum nie wykluczy się głosów niżej uposażonych, Romów, czarnoskórych kobiet, itd.? U Dean problem ten się pojawia, jednak jedyne, co otrzymujemy jako odpowiedź, to afirmację wertykalnej struktury, czyli pogłębienie wykluczenia.

44 Tamże, s. 243-245.

45 J. Bednarek, Polityka poza forma, s. 134.

46 J. Dean, The Communist Horizon, s. 211.

47 J. Sowa, Ciesz się, późny wnuku!, s. 441.

48 H. Cleaver, Polityczne czytanie Kapitału, tłum. I. Czyż, Poznań 2011, s. 193.

49 Tamże, s. 194-195. 
Powtarzana jak mantra zasada „polityka bez partii to polityka bez polityki” prowadzi czytelniczkę książki do wniosku ${ }^{50}$, iż działania Occupy Wall Street nie są formą demokracji bezpośredniej, lecz bezsensownym „sloganowaniem”. Jeśli przyjąć założenia Badiou i Žižka o autonomii sfery polityki względem produkcji, faktycznie bezsensowne staje się uprawianie polityki w niewyznaczonych do tego miejscach. Jednakże w świetle realnej subsumcji życia pod kapitał, która sprowadza się do objęcia wszystkich stosunków społecznych relacją wyzysku, polityczna strategia powinna uwzględniać szeroki, biopolityczny teren walk $k$ lasowych ${ }^{1}$. Stanowisko Dean i jej nauczycieli jawi się w związku z powyższym jako nieuzasadnione.

Radykalna zmiana, jakiej domagają się ruchy antykapitalistyczne, zachodzi nie tylko na poziomie treści (dobra wspólnego zamiast publicznego/prywatnego), ale również formy. Podstawowe pytanie stanowi: jak ludzie mogą współpracować ze sobą i zarządzać dobrem wspólnym w ramach demokratycznego procesu podejmowania decyzjii ${ }^{52}$ ? Jodi Dean, opisując partię jako panaceum na wszystkie bolączki polityki lewicowej, nie dostrzega potencjału rewolucyjnego w materialnych warunkach współczesnego systemu społeczno-gospodarczego. Próba narzucenia psychoanalitycznego kaftana ruchom społecznym skończyłaby się źle - zwłaszcza że to sami protestujący odmawiają pójścia za radą politycznych psychoanalityków ${ }^{53}$.

W moim odczuciu niechęć ta zdaje się czymś słusznym. Książka The Communist Horizon Jodi Dean nie uwzględnia historycznych przeformułowań w „fizjologii walki klas”. Publikacja amerykańskiej lacanistki bardziej przypomina pamflet z dziedziny fikcji politycznej, który swojego czasu napisał o Stanach Zjednoczonych Lew Trocki ${ }^{54}$, niż analizę zaangażowanej badaczki, która przybliża nas do określenia realistycznych możliwości organizacji walk antykapitalistycznych. I jako ahistoryczna fikcja powinna zostać potraktowana.

50 Czemu daje wyraz w wywiadzie nt. książki: http://www.counterpunch. org/2013/07/11/admitting-the-communist-desire/

51 A. Negri, Przedmowa do wydania polskiego, w: K. Marks, Kapitat 1.1.: Rezultaty bezpośredniego procesu produkcji, ttum. M. Ratajczak, Warszawa 2013, s. X-XII

52 M. Hardt, A. Negri, Declaration, s. 39.

53 P. Mason, Skąd ten bunt?, s. 84-85, 254-255.

54 http://lewica.pl/index.php?id=17856\&tytul=Kuro\%F1:-My\%B6l-musiby\%E6-wolna

Publikacja

amerykańskiej lacanistki bardziej przypomina pamflet z dziedziny fikcji politycznej, który swojego czasu napisał o Stanach Zjednoczonych Lew Trocki, niż analizę zaangażowanej badaczki, która przybliża nas do określenia realistycznych możliwości organizacji walk antykapitalistycznych 
BARTOSZ ŚLOSARSKI - sekretarz redakcji „Praktyki Teoretycznej”, student Międzyobszarowych Studiów Humanistycznych i Społecznych UAM. Publikował m.in. w „Le Monde Diplomatique - Edycja polska” i „Bez Dogmatu”.

\section{Dane adresowe autora:}

Bartosz Ślosarski

Pracownia Humanistycznych Studiów Interdyscyplinarnych UAM

Collegium Maius

ul. Fredry 10

60-598 Poznań

e-mail: b.slosarski@gmail.com

Cytowanie: B. Ślosarski, Czerwony horyzont marzeń, „Praktyka Teoretyczna" nr 3(9)/2013, http://www.praktykateoretyczna.pl/PT_nr9_2013_ Po_kapitalizmie/14.Slosarski.pdf (dostęp dzień miesiąc rok) 